\title{
Indikator Kebahagiaan (Al-Sa'adah) dalam Perspektif Alquran dan Hadis
}

\author{
Nanum Sofia \\ Endah Puspita Sari
}

Program Studi Psikologi, Fakultas Psikologi dan Ilmu Sosial Budaya Universitas Islam Indonesia, Yogyakarta

\begin{abstract}
Happiness is the most essential thing for human life. There are various indicators of happiness, but there are no indicators that use the Islamic perspective. This study aims to examine indicators of happiness (al-sa'adah) in an Islamic perspective that refers to and guided primarily by the Koran and Hadith. This study uses literature studies, by collecting verses from the Koran and Hadith related to the concepts of happiness in Arabic. The researcher found that overall, there are 164 verses from 122 letters of the Koran and 24 theorem of hadiths. Based on the search for arguments and verses related to happiness (al-sa'adah), researchers found 17 indicators of happiness according to the The Qoran and Hadith, namely: Faith and takwa (50 verses), tafaqquh fid-dien ( 2 verses), pious charity (23 verses), patience ( 7 verses), thanksgiving (7 verses), tazkiyatun al-nafs ( 2 verses), amar ma'ruf nahi munkar ( 3 verses), jihad fi sabilillah (5 verses), seeking and receiving the blessing of Allah (10 verses), dzikr (3 verses), get the gift / mercy from Allah (28 verses), ishlah (7 verses), uswah hasanah (2 verses), seek Allah's protection ( 2 verses), surrender ( 3 verses), reject evil with goodness ( 3 verses) and keeping oral and deeds (5 verses).
\end{abstract}

Keyword: al-sa'adah, happiness, Islamic perspective, The Quran \& Hadith

Abstrak. Kebahagiaan merupakan hal yang paling esensial bagi kehidupan manusia. Terdapat beragam indikator kebahagiaan, namun belum ada indikator yang berorientasi dan menggunakan perspektif Islam. Oleh sebab itu, penelitian ini dilakukan dengan tujuan untuk menelaah indikator kebahagiaan (al-sa'adah) dalam perspektif Islam yang merujuk dan berpedoman utama pada Alquran dan Hadis. Penelitian ini menggunakan studi literatur, dengan cara mengumpulkan ayat-ayat Alquran dan Hadis terkait konsep-konsep kebahagiaan dalam bahasa Arab. Secara keseluruhan, terdapat 164 ayat dari 122 surat Alquran dan 24 dalil hadis yang peneliti temukan. Berdasarkan penelusuran dalil dan ayat terkait kebahagiaan (alsa'adah), peneliti menemukan 17 indikator kebahagiaan menurut Alquran dan Hadis, yaitu iman dan takwa (50 ayat), berpegang teguh pada agama (tafaqquh fi al-dien) (2 ayat), berbuat baik (amal saleh) (23 ayat), sabar (al-shabr) (7 ayat), syukur (al-shabr) (7 ayat), penyucian jiwa (tazkiyatun al-nafs) (2 ayat), menyeru pada kebaikan dan melarang kemungkaran/perbuatan buruk (amar ma'ruf nahi munkar) (3 ayat), berjuang di jalan Allah (al-jihad fi sabilillah) (5 ayat), mencari dan mendapat rida Allah (10 ayat), mengingat Allah (al-dzikr) (3 ayat), mendapat karunia/rahmat Allah (28 ayat), memperbaiki diri (al-ishlah) (7 ayat), memberi teladan (uswah hasanah) (2 ayat), mencari perlindungan Allah (2 ayat), berserah diri (3 ayat), menolak kejahatan dengan kebaikan (3 ayat) serta menjaga lisan dan perbuatan (5 ayat).

Keyword: al-sa'adah, Alquran \& Hadis, kebahagiaan, perspektif Islam

Korespondensi: Nanum Sofia. E-mail: nanumsofia@uii.ac.id. 
Salah satu tujuan utama manusia hidup di dunia adalah memperoleh kebahagiaan. Kebahagiaan merupakan konsep yang sangat dan jamak diminati oleh para peneliti. Sebanyak 668.050 jurnal penelitian tentang kebahagiaan di tahun 2015 terdokumentasi dalam berbagai jurnal, di antaranya Ebscohost 6.945 penelitian, Jstor sebanyak 171.067, Oxford Journals 18.296, serta ProQuest tercatat memiliki dokumentasi terbanyak yaitu 471.742. Minat yang besar untuk meneliti kebahagiaan ini disebabkan bahwa hakikat hidup manusia adalah untuk memperoleh kebahagiaan.

Sayangnya, tidak semua manusia memahami hakikat kebahagiaan yang sesungguhnya. Kebahagiaan bersifat abstrak. Definisinya pun sangat subjektif dan beragam. Dalam Perspektif Barat, para pakar yang tertarik dengan konsep utama psikologi positif ini seringkali menggunakan istilah yang berbeda-beda dalam mendefinisikan atau menggunakan konsep kebahagiaan. Seligman merupakan tokoh atau ahli yang banyak mempengaruhi penelitian tentang kebahagiaan dengan konsepnya yang terkenal "authentic happiness" (Seligman 2013). Tokoh lain menggunakan istilah yang sama, mirip, atau juga berbeda namun bermakna sama, yaitu episodic happiness yang dicetuskan oleh Feldman (2010), Kekes (Rahmat, 2004); emotional state theory of happiness (Davis,
Sumner, \& Kahneman dalam Raibley, 2012), dan juga subjective well-being (Diener, 2000).

Implikasi dari beragam konsep dan definisi, menjadikan kebahagiaan memiliki berbagai tolak ukur. Konsep kebahagiaan dapat ditelusuri kemunculannya sejak sebelum masehi dari pemikiran Filsuf Yunani Kuno, Kyrene di masa Aristippos (sekitar 433-355 SM) bahwa kenikmatan itu bersifat badani. Konsep inilah yang disebut hedonic (hedone [Yunani]: nikmat, kegembiraan). Hedonisme merupakan aliran yang mengusung kenikmatan sebagai kebaikan tertinggi, berharga. Hal yang utama adalah bukan sifat nikmatnya, melainkan jumlah nikmatnya (Ahnan, 2014).

Konsep kebahagiaan kemudian dikembangkan oleh Aristoteles (384-322 SM) dengan pemikiran yang berbeda. Aristoteles menjelaskan bahwa tindakan dan hidup manusia selalu memiliki arah, tujuan antara, dan tujuan akhir. Adapun tujuan tertinggi manusia (tujuan akhir atau utama) ialah kebaikan. Kebaikan tertinggi dari manusia disebutnya sebagai kebahagiaan. Lebih lanjut, Aristoteles mendefinisikan kebahagiaan sebagai tindakan jiwa yang selaras dengan keutamaan sempurna, yang dalam bahasa Yunani disebut sebagai psyche (jiwa yang rasional) dan arête yaitu keutamaan sebagai manusia yang baik berupa keutamaan 
moral dan intelektual (Garvey, 2010). Pemikiran Aristoteles ini kemudian dikenal dengan konsep eudaimonia (dari bahasa Yunani yang berarti kebahagiaan).

Bertolak dari dua perspektif di atas, muncullah konsep-konsep kebahagiaan di masa kini yang bersumber dari perspektif hedonic dan eudaimonic, misalnya konsep well-being. Tak berhenti sampai di sini, pemikiran tentang kebahagiaan kian variatif dan memiliki tolak ukur yang beragam. Beberapa pakar mendesain pengukuran kebahagiaan melalui faktor ektsernal dan sebagian yang lain melalui faktor internal. Beberapa pakar yang fokus terhadap aspek internal kebahagiaan ialah Seligman (2013), dalam buku Beyond Authentic Happiness, bahwa kebahagiaan diukur dari kepuasan hidup seseorang. Semakin tinggi tingkat kepuasan, maka tingkat kebahagiaan individu semakin tinggi. Demikian juga dengan Diener (1985; 2000) yang mengembangkan alat ukur subjective well-being yang melihat ranah kognitif dan afektif. Watson, Clarck dan Tellegen (1988) juga berusaha mengukur kebahagiaan yang berasal dari dalam diri individu berupa afek positif dan afek negatif yang diukur melalui PANAS scale. Selain alat ukur di atas, banyak sekali alat ukur kebahagiaan (happiness) yang lain seperti Oxford Happiness Inventory (Hill \& Argyle, 2002), Subjective Happiness (Lyubomirsky \& Lepper, 1999), serta Satisfaction with Life Scale (Diener, Emmons, Larsen and Griffin,
1985), serta alat ukur kesejahteraan psikologis lain yang dikumpulkan oleh Schiaffino (2003) yang memuat beberapa alat ukur yaitu The Affect Balance Scale (ABS), General Health Questionnaire (GHQ12), Life Satisfaction Index-A (LSI-A), Rosenberg Self-Esteem Scale, Satisfaction with Life Scale (SWLS), serta State-Trait Anxiety Index (STAI).

Menariknya, pengukuran kebahagiaan pun mulai bergeser cakupannya, tak lagi bersifat personal, melainkan global. Dikutip Hartanto (2007), seorang psikolog sosial bernama Adrian White dari Universitas Leicester Inggris menerbitkan Peta Kebahagiaan Dunia (Global Map of Subjective Well-Being) dengan menggunakan data-data dari United Nations of Educational, Scientific, and Cultural Orgnization (UNESCO), The New Economics Foundation, World Health Organization (WHO), United Nations High Commissioner for Refugees (UNHCR), Latinbarometer, bahkan data Central Intellegence Agency (CIA). Melibatkan 80 ribu responden, penelitian kebahagiaan ini mengaitkan dengan tingkat kesehatan, kemakmuran, dan pendidikan warga suatu negara. Berdasarkan pemetaan itu, Denmark merupakan negara terbahagia sedunia. Di sisi lain, Burundi merupakan negara yang paling tidak bahagia jika dibandingkan dengan negara-negara lain. Sementara itu, Indonesia berada di urutan ke-64 dunia. Malaysia di urutan ke-17, 
Australia ke-26, dan Papua Nugini di urutan ke-86.

Tak ingin kalah dari Inggris, Amerika Serikat melalui laporan survey pertamanya di tahun 2012 membuat laporan "World Happiness Report" yang bertujuan mengukur kebahagiaan suatu negara dalam rangka membantu warganya guna membuat kebijakan publik (Chirzhin, 2015). Lembaga survey yang dimotori Helliwell, Layard, dan Sach (2017) dari University of British Columbia ini secara berkala mengukur kebahagiaan negaranegara di dunia menggunakan tiga elemen kebahagiaan, yaitu melalui evaluasi hidup (life evaluation), afek (affect), serta kepuasan hidup (eudaimonic). Hasilnya, Norwegia, Denmark, Islandia, Swiss, serta Finlandia, secara urut menjadi 5 negara paling bahagia di dunia pada tahun 2017, sementara Indonesia berada di urutan ke81. Hasil survey ini berubah di tahun 2019, yang mendudukkan Indonesia di posisi ke92 (turun 11 angka) dengan negara terbahagia yaitu Finlandia.

Survey kebahagiaan dalam cakupan besar lainnya dilakukan oleh Sustainable Development Solutions Network (SDSN), sebuah yayasan di Amerika Serikat, yang menganalisis 185 negara melalui pengukuran terhadap kemampuan ekonomi rakyatnya, neuroscience, statistik kependudukan, serta gambaran tingkat kesejahteraan subjektif yang secara efektif digunakan untuk mengukur kemajuan bangsa (unsdsn.org, 2015). Hasilnya, Swiss menjadi negara di peringkat pertama yang masyarakatnya dianggap paling bahagia di dunia, diikuti oleh Islandia, Denmark, Norwegia, Kanada, Finlandia, Belanda dan Swedia. Amerika sendiri berada di urutan ke-15. Sedangkan negara-negara yang dianggap paling tidak bahagia hingga kurang dan cukup bahagia (The saddester, least "happy") ialah Togo, Burundi, Syria, Benin dan Rwanda (Boyer, 2015).

Survei tentang kebahagiaan yang dilakukan organisasi United Nations Social Development Solution Network (UNSDSN) di USA bukannya tanpa landasan keilmuan. Salah satu kunci utama penelitian ini justru didasarkan pada penelitian psikologis dan neurosains yang menganjurkan bahwa menjaga otak tetap "bahagia" mampu membantu empat hal: 1) tetap positif, 2) menyembuhkan perasaan negatif, seperti kesedihan atau kemarahan, 3) peduli dan menghabiskan waktu bersama keluarga dan teman-teman, serta 4) tetap waspada, meski ada sensasi kekaguman atau kegembiraan (Brodwin, 2015). Penilaian kebahagiaan ini juga menggunakan pengukuran yang lain, yaitu Gross Domestic Product (GDP) per kapita (ekonomi), dukungan sosial, harapan hidup dan kesehatan, kebebasan dalam mengambil pilihan dalam hidup, kedermawanan, persepsi terhadap korupsi, dystopia (melihat masa depan dengan buram), dan warisan (Boyer, 2015). 
Pemaparan di atas menggambarkan bahwa penelitian dan perhatian terhadap kebahagiaan tidak pernah surut. Pun dalam konteks Islam, penelitian tentang kebahagiaan juga kerap dilakukan. Sayangnya kontinuitas penelitian dan perhatian terhadap kebahagiaan yang dilakukan peneliti atau psikolog muslim di negara muslim, masih berkutat pada konseptualisasi teoritis semata, atau bahkan memperdebatkan perbedaan paradigma konsep kebahagiaan itu sendiri, dan menggunakan tolak ukur Barat. Sejatinya, definisi konsep kebahagiaan telah dicetuskan oleh banyak ilmuwan Islam, di antaranya oleh al-Ghazali, al-Farabi, Hasan Hanafi, Ibnu Sina, Ibnu Misykawaih dan Ibnu Bajjah.

Selain itu, beberapa penelitian kebahagiaan dalam konteks Islam juga pernah dilakukan, di antaranya oleh Joshanloo (2013) dengan artikel berjudul "A Comparison of Western and Islamic Conception of Happiness"; Ninin (2015) tentang "The Servant Self-The Ideal Personality for Health and Happiness: A Study on Related Verses in the Quran"; Arifin (2015) meneliti kebahagiaan dengan artikel berjudul "The Psychology of Happiness according to Imam Al-Ghazali: Its Relevance in Understanding Today's Human Happiness"; ada pula Hamdan (2016) yang meneliti tentang "Konsep Happiness ditinjau dari Psikologi Positif dan Psikologi Islam". Survei studi pendahuluan juga dilakukan oleh peneliti dengan menggandeng mahasiswa untuk melakukan mini research guna menggali faktor-faktor yang mempengaruhi kebahagiaan. Dari 927 responden, faktor utama yang mempengaruhi kebahagiaan adalah keluarga, disusul materi, dan kemudian hubungan sosial (Sofia, 2015).

Terlihat bahwa pemikiran dan penelitian di atas hampir semuanya sebatas mewacanakan konsep kebahagiaan saja, belum secara eksplisit membuat indikator pengukuran kebahagiaan yang berlandaskan Alquran dan Hadis. Penelaahan indikator kebahagiaan yang merujuk pada Alquran dan Hadis menjadi penting agar pengukuran kebahagiaan menjadi pas dan tepat bila diterapkan di kalangan masyarakat muslim. Dengan demikian, penelitian ini bermaksud menelaah indikator-indikator kebahagiaan yang merujuk pada Alquran dan Hadis yang diharapkan dapat menjadi cikal bakal pembuatan alat ukur kebahagiaan versi Islam di masa mendatang.

\section{Konseptualisasi Kebahagiaan (Sa'adah)}

Banyak ilmuwan muslim mendefinisikan makna kebahagiaan, baik ilmuwan klasik hingga ilmuwan masa kini. Ibnu Miskawaih mendefinisikan kebahagiaan berdasarkan dua bentuk, yaitu pertama, kebahagiaan badan (materi) yang berada pada tataran yang rendah dan tidak abadi atau bersifat sementara dan kedua kebahagiaan jiwa. Kebahagiaan materi 
mengandung penyesalan, kepedihan, dan menghambat perkembangan jiwa kepada Allah swt. Berbeda dari itu, kebahagiaan jiwa merupakan kebahagiaan sempurna yang mengantar manusia menuju derajat malaikat (Miskawaih, 1999).

Jika Ibnu Miskawaih mensyaratkan kebahagiaan jiwa dan raga (badan/materi) sekaligus, al-Ghazali (2001; 2017) lebih menekankan bahwa esensi kebahagiaan hanya terletak pada jiwa, yang dapat diperoleh melalui pengenalan terhadap diri, Allah, dunia, dan akhirat. Manusia dianggap berbahagia jika mampu mengenali empat hal tersebut. Dari keempat pengenalan tersebut, kebahagiaan jiwa yang tertinggi (atau puncak kebahagiaan) pada manusia ialah jika ia mampu mengenal Tuhannya (ma'rifatullah). Dengan mengenal Tuhannya, maka manusia seakan tidak lagi membutuhkan apapun di dunia, karena kebahagiaan jiwanya telah tercukupi dengan kedekatannya dengan Yang Maha Kuasa.

Kebahagiaan (al-sa'adah) tidak akan dicapai manusia secara tiba-tiba atau apa adanya (taken for granted). Diperlukan cara-cara agar manusia mampu mencapai kebahagiaan hakiki yang menjadi tujuannya. Jika al-Ghazali dalam bukunya “Kimia al-Sa'adah" (2001; 2017) menjelaskan bahwa kebahagiaan dapat diraih saat manusia mampu mengenal diri, mengenal Tuhan, mengenal dunia, dan mengenal akhirat, maka lain halnya dengan
Rahmat (2004), yang mengatakan bahwa kebahagiaan dapat dicapai melalui empat cara yaitu: (1) memahami bahwa segala sesuatu yang terjadi di dunia bersifat sementara; (2) penderitaan terjadi karena ada keinginan, hasrat, nafsu, yang harus dipuaskan; (3) untuk mengakhiri penderitaan, orang harus mengakhiri atau menghentikan keinginan agar jalan menuju nirvana (kebahagiaan, kebebasan) menjadi terbuka; dan (4) nirvana dicapai dengan iman dan latihan ruhaniah.

Hidayat (2013) menjelaskan bahwa kebahagiaan memiliki tahapan yang disebut 'tangga kebahagiaan'. Tangga pertama, ialah kesenangan fisik (physical pleasure), yaitu bahwa kebahagiaan manusia lebih bersifat fisik. Manusia selalu mengejar kenikmatan fisik, sebagaimana menonjol dalam kehidupan hewani, seperti minum, seks, rasa aman. Tangga kedua, yaitu kebahagiaan intelektual (intellectual happiness). Pada tataran jiwa insani, yang ikonnya adalah intelektualitas, seseorang akan menemukan kebahagiaan hidup bukan dari makan, minum, dan seks (kebahagiaan fisik), melainkan lebih abstrak, yaitu kebahagiaan intelektual, bukan lagi kesenangan fisik. Kebahagiaan saat lulus ujian atau memperoleh pengalaman intelektual yang lain akan lebih abadi dibanding dengan sekedar kebahagiaan fisik. Orang tua yang lanjut usia, yang sebagian besar fisiknya sudah menurun, akan tetap bisa meraih kebahagiaan 
intelektual dengan kegiatan membaca buku, menulis, ataupun mengajar.

Pada intinya, kebahagiaan yang diraih jiwa insani memiliki potensi untuk terus berkembang. Tangga ketiga, yakni kebahagiaan moral (moral happiness), yaitu kebahagiaan akan muncul jika pengalaman hidup individu bisa disalurkan kepada generasi selanjutnya, tidak untuk dirinya sendiri. Tangga ketiga ini memperjelas bahwa kebahagiaan justru diperoleh dan lebih bermakna jika seseorang memberi, bukan menerima. Implikasi dari kebahagiaan moral ini menurut Hidayat (2013) kemudian menjadi lebih luas lagi, yaitu tangga keempat, kebahagiaan sosial (social happiness). Saat individu berbagi dengan orang lain, secara tidak langsung ia tengah membangun relasi sosial. Sebuah penelitian sosial menunjukkan, salah satu pilar kebahagiaan hidup adalah jika seseorang memiliki teman atau komunitas yang baik, yang dimulai dari keluarga. Namun, hidup yang dibatasi hanya dalam jaringan keluarga juga tidak cukup sehingga seseorang senantiasa memerlukan relasi sosial dalam masyarakat. Di dalam masyarakat inilah, sesungguhnya sumber kebahagiaan hidup teraktualisasikan, misalnya dengan menolong maupun berbagi kepada sesama teman.

Konsep kebahagiaan sebagaimana dijelaskan di atas merupakan hasil pemikiran dan pemaparan para ahli. Apakah pemikiran tersebut selaras dengan term dan konsep kebahagiaan (al-saadah) sebagaimana termaktub dalam Alquran maupun Hadis inilah yang dieksplorasi dalam penelitian ini. Untuk itulah diperlukan telaah term-term dan konsepkonsep dalam Alquran dan Hadis guna menemukan indikator kebahagiaan yang secara eksplisit muncul dalam ayat Alquran dan dalil Hadis.

\section{Metode}

\section{Desain penelitian}

Penelitian ini menggunakan metode studi literatur dengan Alquran dan Hadis sebagai rujukan utama, sementara pemikiran para tokoh dan mufasir menjadi rujukan tambahan dalam memperkuat pemahaman tentang konsep dan seleksi ayat-ayat kebahagiaan (al-sa'adah). Penelitian ini dilakukan melalui dua tahap. Tahap pertama, peneliti menggunakan pendekatan tekstual/linguistik dengan cara menelusuri arti melalui pencarian arti dari akar kata, yaitu secara etimologis (melalui pencarian akar kata dari ilmu shorof) dan secara terminologis yang digali dari Alquran dan Hadis serta sumber-sumber rujukan lainnya.

Kedua, peneliti melakukan pendekatan tematik (thematic approach) dari ayatayat Alquran dan Hadis melalui metode tafsir mawdhu'i (tafsir tematik) yang dilakukan dengan beberapa langkah, yaitu: 1) peneliti melakukan penelusuran ayat yang dilakukan dengan menggunakan aplikasi "Zekr" yang dapat diunduh di 
Microsoft Office maupun Macbook. Penelusuran ayat dilakukan setelah sebelumnya dilakukan seleksi kata yaitu alsa'adah dan sinonimnya, serta kata lain yang mirip atau yang memiliki "makna bahagia"; 2) menghimpun ayat-ayat alsa'adah dan term lain yang semakna; dan memahami kandungannya; 3) memahami korelasi ayat-ayat untuk memahami konsep al-sa'adah secara global; 4) setelah didapat pemaha-man tersebut, maka dilakukan penyusunan indikator al-sa'adah; 5) melengkapi pembahasan dengan HadisHadis yang relevan dengan pokok bahasan agar lebih komprehensif. Adapun tafsir tematik yang peneliti lakukan bukan dalam rangka menafsirkan ayat-ayat sebagaimana yang dilakukan para mufasir, melainkan hanya untuk memahami konteks dari ayatayat tersebut.

\section{Hasil}

\section{Seleksi ayat (Alquran)}

Rekonstruksi konsep kebahagiaan menurut perspektif Islam dalam penelitian ini didasarkan pada Alquran dan Hadis. Berikut ini ialah hasil telaah konsep-konsep kebahagiaan melalui pendekatan tekstual atau linguistic approach (etimologis dan terminologis) serta pendekatan konseptual:

\section{Pendekatan tekstual (linguistic approach)}

Secara etimologis, dalam kamus Arab-Indonesia versi Yunus (2007) akar kata al-sa'adah berasal dari kata sa'ida(سعد)yas'adu (يسعد) su'ida (سعد) sa'aadatan ( سعادة) yang bermakna "berbahagia, beruntung". Dalam lafal yang lain disebutkan sebagai sa'ada-yas'adu-sa'dan-su'uudan, ang bermakna (hari) baik, mujur, atau tidak sial. Dalam konteks ini, yang dimaksud alsa'adah ialah adalah sebagaimana tertulis di awal, yaitu sa'ida-yas'adu-su'ida-sa'aadatan alias berbahagia atau beruntung, kegembiraan, keceriaan.

Secara terminologis, lafal al-sa'adah memiliki banyak makna jika ditelusuri dari akar kata sa'adah. Di antaranya ialah (hari) baik, mujur, tidak sial (sa'ada-yas'adusa'dan-su'uudan), tanda baik, mujur, tak sial (sa'uda-as'udu-su'uudan), menolong (saa'ada), yang berbahagia (mas'uud, atau masaa'id), ketua atau kepala (as-saa'id), yang menolong atau membantu (musaa'id), serta pertolongan (musaa'adah) (Yunus, 2007). Dalam Jami'u al-huquq al-mahfudzah (2011) al-sa'adah merupakan lawan kata dari syaqiyya yang bermakna sedih atau tidak bahagia.

Secara bahasa, lafal al-sa'adah di dalam Alquran memiliki beragam term atau istilah yang mirip atau memiliki makna yang kurang lebih sama. Di antaranya ialah falah (kemenangan) yang dalam tafsir alAzhar dimaknai sebagai kebahagiaan (Hamka, 2015), fauz (kemenangan), farah (bahagia), suruur (kebahagiaan), busyro (kabar gembira), tuuba (berbahagia, sentosa), toyyib (yang baik, yang bagus), hasanah (yang baik), serta al-salaam (kedamaian, keselamatan). Penelitian yang 
dilakukan Sholihah (2016) membatasi definisi kebahagiaan hanya dalam tiga konsep saja, yaitu falah (kemenangan), farah (kegembiraan), dan fauz (kemenangan). Sementara, penelitian Fuad (2016) sedikit lebih komprehensif, yaitu menggunakan istilah falah (kemenangan), farah (kegembiraan), fauz (kemenangan), tuubaa (berbahagia), thoyyib (yang baik), saiid/sa'aadah (kebahagiaan), hasanah (kebaikan), barakah (berkah), as-salaam (kedamaian, keselamatan), muthmainnah (ketenangan), as-syarh (kelapangan), serta sakiinah (kedamaian, ketenangan). Dalam penelitian ini, peneliti menggabungkan semua term di atas untuk kemudian memahami makna dan menyeleksi ayatayat yang dapat dirujuk dalam pembuatan aitem-aitem pada alat ukur sa'adah ini dengan menambahkan beberapa term yang merujuk pada makna bahagia, yaitu busyro (kabar gembira) dan surur (kegembiraan).

2. Pendekatan konseptual melalui telaah Alquran dan Hadis

Penelusuran secara rinci ayat-ayat sa'adah diperoleh 164 ayat Alquran dan 24 Hadis yang terangkum di bawah ini:

Tabel 1. Term atau konsep-konsep al-sa'adah berdasarkan akar kata dan sinonimnya

\begin{tabular}{|c|c|c|}
\hline No & $\begin{array}{l}\text { Konsep-konsep al-Sa'adah \& } \\
\text { term yang } \\
\text { berdekatan/memiliki makna } \\
\text { sama/mirip }\end{array}$ & Sumber/Rujukan dalil \\
\hline 1. & $\begin{array}{l}\text { Saiid/Sa'adah: سعيد (yang } \\
\text { berbahagia) }\end{array}$ & QS. Huud: 105, 108. \\
\hline 2. & $\begin{array}{l}\text { Falah, yang bersumber dari kata: } \\
\text { قد افلح (sungguh berbahagia) }\end{array}$ & $\begin{array}{l}\text { QS. as-Syams: 9, al-A'la: } 14 \text {, Thaha: } 64 \text {, dan al-Mu'minun: } \\
1 .\end{array}$ \\
\hline 3. & $\begin{array}{l}\text { Falah, yang bersumber dari } \\
\text { kata: مفحون (orang-orang yang } \\
\text { berbahagia/beruntung) }\end{array}$ & $\begin{array}{l}\text { QS. al-Baqarah: 5, 189; ali Imran: } 104,130,200 \text {; al-Maidah: } \\
\text { 35, 90, 100; al-An'am: 21,135; al-A'raf: 8, 69, 157; al- } \\
\text { Anfaal: 45; at-Taubah: 88; Yunus: 17,69,77,23; an-Nahl: } \\
\text { 116; al Kahfi:20; Thaha: 69; al-Hajj: 77, al-Mu'minun: 102, } \\
\text { 117; an- Nur: 31, 51; al-Qashash: 67,82; ar-Ruum: 38; } \\
\text { Luqman: 5; al-Mujadalah: 22; al-Hasyr:9; al-Jum'ah: 10; } \\
\text { dan at-Taghabun: } 16 .\end{array}$ \\
\hline
\end{tabular}

4. Farah: فرح (senang)

QS. Ali Imran: 120, 170, 188; al-An'am: 44; at-Taubah: 50, 81; Yunus: 22, 58; Huud: 10; ar-Ra'du: 26,36; alMu'minun: 53; an-Naml: 36; al-Qashash: 76; ar-Ruum; 4, 32, 36; al-Ghafir: 75,83; asy-Syuuraa: 48; dan al-Hadiid: 23.

5. Fauz: فوز (keberuntungan) QS. an-Nisa: 13, 73; al-Maidah: 119; al-An'am: 16; atTaubah: 72, 89, 100, 111; Yunus: 64; al-Ahzab: 71, ashShaffat: 60; al-Ghaafir: 9; ad-Dukhan: 57; al-Fath: 5; alHadid: 12, ash-Shaff: 12; at-Taghabun: 9, dan al-Buruj: 11. 


\begin{tabular}{|c|c|c|}
\hline No & $\begin{array}{c}\text { Konsep-konsep al-Sa'adah \& } \\
\text { term yang } \\
\text { berdekatan/memiliki makna } \\
\text { sama/mirip }\end{array}$ & Sumber/Rujukan dalil \\
\hline 6. & Suruur: سرور (kegembiraan) & QS. Al-Insyiqaq: 9, 13. Al-Insan: 11. \\
\hline 7. & Tuubaa: طوبي (berbahagia) & QS. Ar-Ra'du: 29. \\
\hline 8. & Busyro: بشري (kabar gembira) & $\begin{array}{l}\text { Q.S. An-Naml: 2; Huud: 69, 74; Al-Furqon: 22; Az-Zumar: } \\
\text { 17; An-Nahl: 89, 102; Yunus: 64, Al-An'am: 48; An-Nisa': } \\
\text { 165; Al-Ankabut: 31; Ali Imron: 126; Al-Anfal: 10; Al- } \\
\text { Ahqaf: 12; Al-Baqarah: 97, 21; Yusuf, 19; Al-Kahfi: } 56 .\end{array}$ \\
\hline 9. & $\begin{array}{l}\text { Toyyib/Baik, dari kata: حياة طيبة } \\
\text { (kehidupan yang baik) }\end{array}$ & QS. an-Nahl: 97. \\
\hline 10. & $\begin{array}{l}\text { Hasanah: حسنة (kebaikan, yang } \\
\text { baik) }\end{array}$ & $\begin{array}{l}\text { QS. at-Taubah: 50; ar-Ra'du: 6,22; an-Nahl: 30,41,122,125; } \\
\text { an-Naml: 46,89; al-Qashash: 54, } 84 \text {; al-Ahzab: 21; az- } \\
\text { Zumar: 10; Fushshilat: } 34 \text {; as-Syuura: } 23 \text {; dan al- } \\
\text { Mumtahanah: } 4,6 \text {. }\end{array}$ \\
\hline 11. & Barakah: بركة (keberkahan) & QS. al-A'raf: 96; Huud: 48, 73; an- Nahl: 127. \\
\hline 12. & Salam/Aslam: سلام (keselamatan) & $\begin{array}{l}\text { QS. al-Maidah: 16; al-An'am: 125, 127; al-A'raf: 46; at- } \\
\text { Taubah: 74; Yunus:10, 25; Huud: 48,69; ar-Ra'du: 24; } \\
\text { Ibrahim: 23; Al-Hijr: 46, 52; an-Nahl: 32, Maryam: } \\
\text { 33,47,62; Thaha: 47; al- Anbiyaa: 69; al-Furqaan: 63,75; } \\
\text { an-Naml: 59; al-Qashash: 55; al-Ahzab: 44; Yaasiin: 58; as- } \\
\text { Shaffat: 79, 109, 120, 130; az-Zumar: 22, 73; az-Zuhruf: 89; } \\
\text { al-Hujuurat: 17; Qaaf: 34; adz-Dzaariyyat: 25; al-Waaqi'ah: } \\
\text { 91; al-Hasyr: 23; as-Shaff: 7; dan al-Qadr: 5. }\end{array}$ \\
\hline 13. & $\begin{array}{l}\text { Sakiinah: سكينة (ketenangan/ } \\
\text { ketenteraman) }\end{array}$ & QS. al-Baqarah; 248 dan al-Fath: 4, 18. \\
\hline 14. & $\begin{array}{l}\text { Muthmainnah: مطمئنة (yang } \\
\text { tenang) }\end{array}$ & $\begin{array}{l}\text { QS. Ali Imran: 126; al-Maidah: 113; al-Anfaal: 10; ar-Ra'du: } \\
\text { 28; an-Nahl: 112; dan al-Fajr: } 27 .\end{array}$ \\
\hline 15. & Syarh: شرح (lapang) & $\begin{array}{l}\text { QS. Al-An'am: } 125 \text {; an-Nahl: 106; Thaha: } 25 \text {; az-Zumar: } 22 \text {, } \\
\text { dan al-Insyirah: } 1 .\end{array}$ \\
\hline
\end{tabular}

Adapun rujukan hadis yang berhasil peneliti kumpulkan bersumber dari sahih Bukhari no: 64 (sama dengan no 454), 97, 1054, 1088, 1274, 2924, 5071, dan dari sahih Muslim no: 12, 1656, 1944, 4745, dari sahih Imam Ahmad, no: 1367, 1368, 1518, $2860,3596,4036$, hadis yang diriwayatkan oleh Ibnu Abbas, Anas bin Malik, serta beberapa hadis muttafaq alaih.
Definisi konseptual dari penelusuran di atas ialah bahwa al-sa'adah bermakna "berbahagia, beruntung", (hari) baik, mujur, atau tidak sial, kegembiraan, keceriaan, tanda baik, mujur, menolong, ketua atau kepala (as-saa'id), yang menolong atau membantu (musaa'id), serta pertolongan (musaa'adah) dan merupakan lawan kata dari syaqiyya yang bermakna 
sedih atau tidak bahagia.

Berdasarkan hasil telaah dalil-dalil yang bersumber dari Alquran, maka dapat dijelaskan bahwa ayat-ayat yang membahas masalah kebahagiaan dari term al-sa'adah hanya ditemukan dua ayat saja. Penelusuran term lain yang sinonim dan mirip atau memiliki makna sama dengan alsa'adah kemudian dilakukan dan ditemukan sebanyak 14 term dengan jumlah sebanyak 162 ayat. Sementara itu, hasil penelusuran dalil Hadis diperoleh sebanyak 24 Hadis.

\section{Pembahasan}

Berdasarkan penelusuran ayat-ayat Alquran dan Hadis di atas, diperoleh indikator kebahagiaan sebagai berikut, yaitu iman-takwa, tafaqquh fid-dien, amal saleh, sabar, syukur, tazkiyatun al-nafs, amar ma'ruf nahi munkar, mencari rida Allah dan mendapatkan rida Allah, jihad jiwa dan harta, Ishlah (memperbaiki diri, bertaubat, meminta ampun) mencari perlindungan Allah (berdoa), zikir (mendekatkan diri kepada Allah), mendapat petunjuk, mendapatkan rahmat/karunia Allah, berserah diri, uswah hasanah (suri teladan), menolak kejahatan dengan kebaikan serta menjaga lisan dan perbuatan.

Indikator kebahagiaan tersebut diperoleh melalui pengkategorian atau pencarian kata kunci dari masing-masing ayat dan dalil hadis melalui telaah tematik yang tersirat dari masing-masing ayat. Berikut ini ialah kategorisasi ayat atau dalil berdasarkan indikator yang ditemukan:

Tabel 2. Indikator-indikator kebahagiaan (al-sa'adah) hasil analisis tematik

\begin{tabular}{ll} 
No Indikator & \multicolumn{1}{c}{ Rujukan } \\
\hline 1. Iman-takwa & QS. Al-Mukminun: 1, 117; Al-Baqarah: 5, 97, 189, 248; Ar- \\
& Ruum: 38; Al-Hajj: 77; At-Taghabun: 9, 16; Al-Ankabut: 31; \\
& As-Shaffat: 60; Al-Ghafir: 83; Ar-Ra'du: 36; Thaha: 47, 69; Al- \\
& Anfal: 10; Ali Imran: 130, 200, Az-Zumar: 10, 17, 73; Al- \\
& Maidah: 35, 90, 100, 119, Al-An'am: 21, 48, 135; An-Nahl: 32, \\
& 116; An-Naml: 2, 59; Al-Anbiya': 69; Al-Qashash: 67, Al-Fath: \\
& 4; Al-A'raf: 96, 157, An-Nur: 31, 51; An-Nisa: 13, 165; Al- \\
& Ahzab: 71; Al-Hadid: 12; Al-Insyiqaq: 9; Al-Kahfi: 56; Hud: 48, \\
& 74; Yunus: 64; Al-Hijr: 46; serta Sahih Ahmad no. 1367, 4036; \\
& Sahih Muslim no. 12, 1656, 1944, dan Sahih Bukhari no. 97, \\
& 1088, 5701, dan muttafaq alaihi
\end{tabular}

2. Berpegang teguh pada Al-Kahfi: 20; An-Nahl: 106; serta Sahih Ahmad no 1518 dan agama (tafaqquh fi al- 3596 dien)

3. Berbuat kebaikan (amal Al-Baqarah: 5; Ar-Rum: 38; At-Taghabun: 9, 16; Al-Anfal: 10; saleh)

Al-Ahqaf: 12; Al-Waqi'ah: 91; Maryam: 33, 47; Al-A'raf: 8; AlMukminun: 102; Al-Mujadalah: 22; Al-Hasyr: 9; An-Nahl: 30, 97; As-Syuraa: 23; An-Naml: 89; Yunus: 10, Ibrahim: 23; AlBuruuj: 11; Ar-Ra'du: 29; Al-An'am: 125, 127; Sahih Bukhari 


\begin{tabular}{|c|c|c|}
\hline No & Indikator & Rujukan \\
\hline & & 1274, 5701, Sahih Muslim no. 1656 \\
\hline 4. & Sabar (sabr) & $\begin{array}{l}\text { Ali Imran: 120, 126, 200; Ar-Ra'du: 24; al-Furqan: 75; An- } \\
\text { Nahl: 127: Az-Zumar: } 10\end{array}$ \\
\hline 5. & Syukur (syukr) & $\begin{array}{l}\text { Al-A'raf 8, 69; Al-Qashash: 82; Yunus: 22, 58; Ar-Rum: 34; As- } \\
\text { Syura: 48; An-Nahl: 112; Al-Insyiqaq: } 13\end{array}$ \\
\hline 6. & $\begin{array}{l}\text { Penyucian jiwa } \\
\text { (tazkiyatun al-nafs) }\end{array}$ & As-Syams: 9; At-Taubah: 50 \\
\hline 7. & $\begin{array}{l}\text { Menyeru/mengajak } \\
\text { kepada kebaikan dan } \\
\text { menolak kemunkaran } \\
\text { (amar ma'ruf nahi } \\
\text { munkar) }\end{array}$ & Ali Imran: 104; An-Nahl: 125; Al-A'raf: 157 \\
\hline 8. & $\begin{array}{l}\text { Berjihad/berjuang di } \\
\text { jalan Allah (Al-Jihaadu } \\
\text { fii sabiilillah) }\end{array}$ & Al-Maidah: 35; At-Taubah: 81, 88, 111; As-Shaff: 12 \\
\hline 9. & $\begin{array}{l}\text { Mencari dan mendapat } \\
\text { ridha Allah }\end{array}$ & $\begin{array}{l}\text { Al-Maidah 16, 119; At-Taubah: 72, 89, 100, 111; Al-Fath: 18; } \\
\text { Al-Insan: 11; Al-Mumtahanah: 6; Al-A'raf: } 46\end{array}$ \\
\hline 10 & $\begin{array}{l}\text { Mengingat Allah } \\
\text { (dzikrullah) }\end{array}$ & $\begin{array}{l}\text { Al-Anfal: 45; Al-Jumu'ah: 10; Ar-Ra'du: 28; Sahih Bukhari no. } \\
97\end{array}$ \\
\hline 11. & $\begin{array}{l}\text { Mendapat } \\
\text { rahmat/karunia Allah }\end{array}$ & $\begin{array}{l}\text { An-Naml: 36; Al-Qashash: 76; Al-Mukminun: 53; Al-Jumu'ah: } \\
\text { 10; Al-An'am: 16; Ad-Dukhan: 57; Hud: 48, 69, 73, 108: Al- } \\
\text { Ahzab: 44; Yasin: 58; Ad-Dukhan: 57; As-Shaffat: 79, 109, 130: } \\
\text { Al-Hujurat: 17; Az-Zumar: 22; Al-Fath: 18; Al-Ghafir: 9; Al- } \\
\text { Insyirah: 1; Ar-Rum: 36; Al-Hadid: 23; Ar-Ra'du: 26; Thaha: } \\
\text { 47; Yunus: 25; Al-An'am: 125; Luqman: 5; Sahih Ahmad no. } \\
\text { 1368, 1483, 2860, 4037; HR. Ibnu Abbas, Sahih Bukhari no. } \\
2924\end{array}$ \\
\hline
\end{tabular}

12. Memperbaiki diri (ishlah)

13. Memberi suri teladan (uswah hasanah)

14. Mencari perlindungan Allah

15. Berserah diri

16. Menolak kejahatan/ keburukan dengan kebaikan

17. Menjaga Lisan dan Perbuatan
Al-Qashash: 67; An-Naml: 46; At-Taubah: 4, 74; Al-An'am: 48; Al-Baqarah: 213; An-Nahl: 41, Sahih Ahmad no. 4036

Al-Ahzab: 21; Al-Mumtahanah: 4

Al-Anfal: 10; Hud: 105; Sahih Bukhari no. 64

An-Nisa: 73; An-Nahl: 89, 102

Al-Qashash: 54, 84; Fushilat: 34

Maryam 62, Al-Furqan: 63; Al-Qashash: 55; Ali Imran: 120, 188 
Dari 17 indikator, hanya indikator iman dan takwa yang paling banyak disebut di dalam Alquran dengan 50 ayat yang tercakup dalam 30 surat dan 9 hadis. Indikator kedua yang paling banyak disebut ialah mendapat rahmat/karunia Allah yaitu sebanyak 28 ayat yang tercakup dalam 24 surat dan 6 hadis, disusul dengan indikator amal saleh sebanyak 23 ayat yang tercakup dalam 19 surat dan 3 hadis. Hal ini mengindikasikan bahwa kebahagiaan di dalam Islam sangat erat kaitannya dengan iman dan takwa kepada Allah serta karuniaNya.

Berdasarkan indikator pertama, yaitu iman dan takwa, menyiratkan bahwa hakikat kebahagiaan manusia berada di dalam jiwa dengan cara mendekatkan diri kepada Allah. Cara mendekatkan diri kepada Allah dalam beberapa ayat di indikator ini disebutkan melalui salat malam, salat tahajud, berpuasa, mengerjakan perintah Allah dan menjauhi larangan-Nya, mengikuti sunah Rasul, mencintai Allah dan rasul-Nya, tidak musyrik, tidak bermaksiat kepada Allah, menutup aurat, ghaddu al-bashar (menjaga pandangan), menjaga diri dari makanan haram, serta tidak memakan riba. Dapat dipahami bahwa hanya melalui iman dan takwalah manusia mendapatkan esensi kebahagiaan yang sesungguhnya. Hal ini dikuatkan dengan pendapat imam alGhazali (2001; 2017) bahwa puncak kebahagiaan tertinggi manusia ialah dengan cara ma'rifatullah (mengenal Allah). Ma'rifatullah hanya dapat dicapai bila manusia meningkatkan iman dan takwa. Hasil telaah ini dikuatkan dengan penelitian meta analisis yang dilakukan Stark dan Maier (2016) yang melibatkan 28 penelitian dari 556 penelitian, membuktikan bahwa kebahagiaan berkorelasi dengan religiusitas. Dengan demikian, kebahagiaan pada hakikatnya tidak akan terlepas dari unsur ketuhanan (religiusitas-spiritualitas) sebagai fitrah dasar manusia.

Dalam konteks ini, peneliti menyimpulkan bahwa indikator pertama termasuk dalam kebahagiaan ukhrawi (kebahagiaan akhirat) jika mengacu pada pandangan al-Ghazali (2001; 2017) dan masuk dalam kebahagiaan spiritual (spiritual happiness) jika mengacu pada pendapat Hidayat (2013). Kebahagiaan spiritual (spiritual happiness) yang dimaksud Hidayat (2013) ialah bahwa sikap, perilaku, dan pikiran manusia senantiasa tertuju hanya kepada Allah, membaca ayat-ayat Allah dan melangkah kemana pun selalu dalam rangka menyebarkan vibrasi salam (kedamaian).

Pada indikator terbanyak kedua, yaitu mendapat rahmat/karunia Allah, dapat diartikan sebagai kebahagiaan immateriil dan materiil sekaligus. Beberapa rahmat atau karunia yang termaktub dalam ayat-ayat ini di antaranya ialah: mendapat nikmat rezeki, mendapat harta benda, pasangan atau keluarga yang baik, 
lingkungan sosial yang baik, terjauhkan dari fitnah, terlindung dari musibah atau bencana, mendapat rahmat iman-Islam, mendapat karunia umur panjang, mendapat kemudahan dalam berbuat kebaikan atau kebajikan, mendapat petunjuk dari Allah, serta mendapat kelapangan dada dalam ber-Islam. Dalam konteks ini, peneliti menyimpulkan bahwa indikator mendapat rahmat Allah masuk dalam kategori kebahagiaan dunia.

Indikator terbanyak ketiga ialah amal saleh. Amal saleh atau amal baik yang tersirat dalam ayat-ayat kebahagiaan ini di antaranya ialah membantu orang lain, mendahulukan orang lain, berinfaq, bersedekah, saling menyayangi sesama dan juga menyayangi non muslim, mendoakan kebaikan bagi orangtua dan orang lain, menghilangkan kesusahan atau gangguan bagi orang lain, serta rendah hati. Indikator amal saleh inilah yang dalam kebahagiaan versi Barat paling ditekankan, yaitu membantu orang lain sebagaimana penelitian Post (2005) yang menjelaskan bahwa sikap altruisme merupakan kunci kebahagiaan dan kesehatan. Hal ini juga selaras dengan prinsip utilitarianisme tentang summumbonum, yaitu bahwa guna mencapai kebahagiaan, tindakan manusia harus diarahkan pada asas utility atau manfaat (Ahnan, 2014).

Indikator yang lain, yaitu sabar, syukur, mencari dan mendapat ridha Allah, memperbaiki diri (ishlah), amar ma'ruf nahi munkar, penyucian jiwa (tazkiyatun alnafs), mengingat Allah (dzikrullah), berserah diri, uswah hasanah, mencari perlindungan Allah, jihad fii sabilillah, serta tafaqquh fid-dien merupakan proses pencapaian kebahagiaan yang bersumber dari perilaku. Umat Islam sebagai hamba Allah dalam konteks ini diharapkan mampu menerapkan perilaku tersebut jika ingin mendapat kebahagiaan jiwa yang sesungguhnya. Beberapa penelitian versi Barat meneguhkan temuan ini. Di antaranya ialah Watkins, Woodward, Stone, dan Kolts (2003) yang menemukan bahwa bersyukur (gratitude) merupakan komponen terpenting dari kebahagiaan.

Kebahagiaan dalam perspektif Islam yang bersumber dari Alquran dan Hadis yang dalam hal ini mengacu pada pedoman Islam atau agama, bukan berarti mengecilkan atau mempersempit cakupan penerapan kebahagiaan hanya untuk umat Islam saja. Sebagai agama rahmatan lil 'alamin, kebahagiaan versi Islam yang bersumber dari Alquran dan Hadis ini dapat menerobos lintas batas negara, ras, geografi, suku, serta gender. Inilah yang disebut sebagai universalitas Islam. Pengecualiannya hanya terjadi pada ridha Allah dan rahmat Allah, bahwa manusia yang mendapat ridha Allah dan rahmatNyalah (terutama rahmat iman-Islam) yang akan mendapat kebahagiaan sejati dan paripurna. Pada indikator lain, non muslim 
juga bisa meraih kebahagiaan dan diukur menggunakan alat ukur versi Islam.

Terlepas dari berbagai kekurangan dalam penelitian ini, sebagai studi pendahuluan, hasil temuan penelitian ini selanjutnya akan dijadikan sebagai bahan dasar pembuatan alat ukur kebahagiaan menurut Alquran dan Hadis.

\section{Simpulan}

Hasil telaah yang dilakukan dalam penelitian ini melalui eksplorasi dalil-dalil yang bersumber dari Alquran dan Hadis, telah menemukan sebanyak 17 indikator alsa'adah. Eksplorasi ini dilakukan melalui penelusuran term al-sa'adah dan term/ konsep lain yang mirip atau memiliki makna sama, dan ditemukan sebanyak 15 term. Dari term-term tersebut, kemudian ditemukan sebanyak 164 ayat Alquran (dari 122 surat) dan 24 dalil Hadis yang menjadi indikator al-sa'adah (kebahagiaan) yang bersumber dari Alquran dan Hadis.

\section{Daftar Pustaka}

Ahnan, M. (2014). Kebahagiaan dalam tasawuf: Komparasi pemikiran Hamka dan Ghazali. Jurnal Refleksi, 14(1), 67-81.

Al-Ghazali, A.H. (2001). Kimiya al-sa'adah: Kimia ruhani untuk kebahagiaan abadi (Terjemahan Dedi Slamet Riyadi \& Fauzi Bahreisy). Jakarta: Zaman.
(2017). Majmu'at rasa'il alImam Al-Ghazali: Kimia sa'adah (Al-Thab'ah Al-Sabi'ah). Beirut, Lebanon: Dar Al-Khotob AlIlmiyah.

Arifin, M.S. (2015). The psychology of happiness according to Imam AlGhazali: Its relevance in understanding today's human happiness. Iconipsy Book of Abstract. Yogyakarta: The $2^{\text {nd }}$ International Conference on Islamic Psychology.

Boyer, L. (2015). These are the 20 happiest countries in the world. US News. Diunduh dari http://www.usnews. com/ news/articles/2015/04/24/ world-happiness-report-ranksworlds-happiest-countries-of2015.

Brodwin, E. (2015). Science says these are the happiest countries in the world. Bussiness Insider. Diunduh dari http://www.businessinsider.co.id/ new-world-happiness-report2015-2015-4/?r=US\&IR=T\#. Vvgu03C9yME.

Diener, E. (2000). Subjective well-being: The science of happiness and a proposal for a national index. American Psychologist, 55(1), 3443.

Diener, E., Emmons, R.A., Larsen, R.J., \& Griffin, S. (1985). The satisfaction with life scale. Journal of Personality Assessment, 49, 71-75.

Chirzhin, H. (2015, September). Peace and happiness, the need of a new epistemology and textbook writing. Makalah dipresentasikan pada Seminar Human Happiness and Integration of Knowledge, Sidoarjo: Fakultas Psikologi Universitas Muhammadiyah Sidoarjo (UMSIDA). 
Feldman, (2010). Whole life satisfaction concept of happiness. Chapter five. Oxford University Press. Diunduh dari http://www.colorado.edu/ philosophy/ heathwood/pdf/ feldman_wlsch.pdf.

Fuad, M. (2016). Psikologi kebahagiaan dalam Al-Qur'an: Tafsir tematik atas ayat-ayat Al-Qur'an tentang kebahagiaan (Laporan penelitian). Lembaga Penelitian dan Pengabdian Masyarakat, Institut Agama Islam Negeri Purwokerto.

Garvey, J. (2010). 20 karya filsafat terbesar. Yogyakarta: Kanisius.

Hartanto, B. (2007). Global map of subjective well-being. Media Indonesia. Diunduh dari: http://mediaindonesia.com.

Hamdan, S.R. (2016). Konsep Happiness ditinjau dari Psikologi Positif dan Psikologi Islam. Makalah dipresentasikan pada the $2^{\text {nd }}$ International Conference on Islamic Psychology, October 9-16, Yogyakarta, Indonesia.

Hamka. (2015). Tafsir al-azhar. Yogyakarta: Gema Insani Press.

Helliwell, J.F., Layard, R., \& Sachs, J. (2017). World Happiness Report: 2017.

(2019). World Happiness Report: 2019.

Hidayat, K. (2013). Psikologi kebahagiaan: Merawat bahagia tiada akhir. Bandung: Noura Books.

Hills, P., \& Argyle, M. (2002). The oxford happiness questionnaire: A compact scale for the measurement of psychological well-being. Personality and Individual Differences, 33, 10731082.
Jami'u -al Huquq al-mahfudzah. (2011). AlMunjid fi-al-lughah wa al-a'lam. (Al-thab'ah al-rabi' wa al-arbain). Birut, Lebanon: Dar al-Masyriq.

Joshanloo, M. (2013). A Comparison of western and Islamic conception of happiness. Journal of Happiness STUDIES, 14, 1857-1874.

Lyubomirsky, S., \& Lepper, H.S. (1999). A measure of subjective happiness: Preliminary reliability and construct validation. Social Indicators Research, 46, 137-155.

Ninin, R.H. (2015). The servant self, the ideal personality for health and happiness: A study on related verses in the Quran. Iconipsy Book of Abstract. Yogyakarta: The $2^{\text {nd }}$ International Conference on Islamic Psychology.

Miskawaih, I. 1999. Menuju kesempurnaan akhlak: Buku daras pertama tentang filsafat etika (terjemahan Helmi Hidayat). Bandung: Mizan.

Post, S.G., (2005). Altruism, happiness, and health: It's good to be good. International Journal of Behavioral Medicine, 12(2), 66-77.

Rahmat, J. (2004). Meraih kebahagiaan. Bandung: Simbiosa Rekatama Media.

Raibley, J.R., 2012. Happiness is not wellbeing. Journal Happiness Study, 13. 1105-1129.

Seligman, M. (2013). Beyond authentic happiness: Menciptakan kebahagiaan sempurna dengan psikologi positif. Bandung: Penerbit Kaifa PT Mizan Pustaka.

Sholihah, I. (2016). Konsep kebahagiaan dalam Al-Qur'an: Perspektif tafsir Mutawalli As-Sya'rawi dan psikologi positif (Tesis). Universitas Islam Negeri Maulana Malik Ibrahim, Malang. 
Sofia, N. (2015). Definisi dan faktor-faktor kebahagiaan (Laporan penelitian, tidak diterbitkan). Yogyakarta: Fakultas Psikologi dan Ilmu Sosial Budaya, Universitas Islam Indonesia.

Stark R., \& Maier, J. (2008). Faith and happiness. Review of Religious Research, 50(1), 120-125.

Unsdsn.org. (2016). World happiness report 2015: Ranks happiest countries. Sustainable Development Solustion Network. A Global Initiative for the United Nation. Diunduh dari http://unsdsn.org/news/2015/04 /23/world-happiness-report2015-ranks-happiest-countries/.

Watkins, P.C., Woodward, K., Stone, T., \& Kolts, R.S. (2003). Gratitude and happiness: Development of a measure of gratitude, and relationship with subjective wellbeing. Social Behavior and Personality, 31(5), 431-452.

Watson, D., Clark, L.A., \& Tellegen, A. (1988). Development and validation of brief measures of positive and negative affect: The PANAS scales, Journal of Personality and Social Psychology, 54(10), 63-70.

Yunus, M. (2007). Kamus Arab Indonesia. Jakarta: Mahmud Yunus wa Dzurriyyah. 
